\title{
Modeling and Implementation of a PV-powered DC Water Pump System for Irrigation in Duhok City
}

\author{
Kerry A. Sado, Lokman H. Hassan \\ College of Engineering, University of Duhok, Duhok, Kurdistan Region - Iraq
}

\begin{abstract}
The agriculture sector nowadays relies mostly on conventional energy sources and traditional irrigation ways. Considering some factors such as high costs of fossil fuels and providing new power lines, especially to remote locations and where grid electricity is either inaccessible or expensive, a solar PV powered irrigation system can be a practical choice for irrigating crop fields. In this paper, a PV-powered dc water pump system design for irrigation is presented. A comprehensive comparison between Direct Current (DC) and an Alternative Current (AC) motors powered by PV is carried out in terms of power, current, water discharge and cost. Dominant factors of the system such as the effect of solar radiation on motor power, current, and water discharge are considered in this study. The optimum tilt angle for Duhok city is considered to perform this study. The specifications of PV, DC and AC motors are tested in Matlab Simulink to show the performance of the system components. The results show that DC motor is preferred over $\mathrm{AC}$ in term of system complexity, cost and power consumption. In contrast, water discharge of $\mathrm{AC}$ pump is slightly higher than the DC pump for the same time. However, overall results demonstrate the superiority of DC motor over AC.
\end{abstract}

KEYWORDS : PV cell, DC motor, Water pumps, Tilt angle, Irrigation.

\section{INTRODUCTION}

Water assumes a critical part in photosynthesis, cooling through transpiration, and is the main thrust for the development of nutrients in the plants. Thus, adequate soil moisture availability is critical in the crop root zone for ideal crop production. Precipitation supplies soil moisture which is available for a plant, and it is consumed through the process of evapotranspiration (crop water use). The rate of evapotranspiration depends mainly upon weather parameters, crop maturity stage, and crop type. Precipitation is deficient in numerous regions of the world, to meet the crop water necessities. Thus, water is utilized by artificial means, like irrigation. Nowadays, $15 \%$ to $20 \%$ of the commonly plowed area is under artificial irrigation, which contributes approximately $40 \%$ of the total agricultural production ((FAO). 2016). Studies show

Academic Journal of Nawroz University (AJNU) Volume 7, No 4 (2018).

Regular research paper : Published 21 December 2018

Corresponding author's e-mail : Kerry.sado@uod.ac Copyright @2017 Kerry A. Sado, Lokman H. Hassan. This is an open access article distributed under the Creative Commons Attribution License. that the crop yield can be expanded by using irrigation along with other extra advantages such as crop improvement in its quality. Various techniques are available for irrigation; from traditional with low application efficiencies ( $40 \%$ to $60 \%$ ) to modernize high efficiencies (70\% to $95 \%)$ such as center pivot, sprinkler, and trickle (dripping) irrigation systems ((FAO). 2016). In Iraq, the center pivot sprinkler and dripping systems are the most commonly adopted irrigation methods. Using renewable and clean energy resources in irrigated farms has raised the significance of solar energy. Utilizing solar radiations as an energy resource is potentially more suitable as compared to the other renewable resources because the crop water requirement is highly depending on incoming solar irradiation. Therefore, the energy production, as well as the energy demand, depends on the same source. (AlAli, Rehman, Al-Agili, Al-Omari, \& Al-Fayezi, 2001) presented a study on the usage of photovoltaic electricity in irrigation systems, using PV cells, backup batteries, controller, and valves. They review the ratings of the electrical equipment (i.e. Motors and controllers) in Saudi Arabia. (Cuadros, López-Rodriguez, Marcos, \& Coello, 2004) and (Hamidat \& Benyoucef, 2009) presented a study for optimal sizing and systematic of 
solar PV irrigation systems. Many factors that affect the proper sizing of solar PV irrigation system are considered. The factors are solar insolation, temperature, weather conditions, the size of PV array, pumping head of the motor, whether the motor pump is AC or DC and type of crops to be irrigated. Choosing the optimal size of solar PV irrigation will significantly increase the efficiency of the system, power production, and reduces overall cost. (Chandrasekaran \& Thyagarajah, 2014) presented a study for validating of AC and DC motor systems fed by PV cells. The study includes a simulation and a practical work. In this study, it is decided that DC motors are more suitable for water pumping applications. However, in this study, critical points such as comparisons of systems costs are not studied and no numerical data provided for total costs. Also, choosing $\mathrm{PV}$ array tilt angle is not mentioned and the effect of tilt angle on PV performance, system power, and water discharge is not discussed. In addition, it mentions that the output voltage of PV array increases with the increase of irradiance, but no numerical data are provided. Tracking and non-tracking solar panels performance have been evaluated in (Helikson, Haman, \& Baird, 1990). It has been understood that the extra cost related to a tracking system can be avoided by setting the panels at some tilt angle, with only a small loss in efficiency. In this paper, a PV-powered dc water pump system is designed for irrigation. A comparison study of the prototype and Matlab Simulink is carried out to demonstrate the advantages and disadvantages of using DC and AC water pumps. Dominant factors of the system such as the effect of solar radiation on motor power, current, and water discharge are studied. Matlab Simulink is also performed to verify the operation the system's components. The rest of the paper is organized as follows: Section 2 describes the modeling of the proposed system. The design of the proposed system is described in section 3, results and discussion are provided in section 4. Finally, the conclusion is provided in section 5 .

\section{SYSTEM MODEL}

Stand-alone photovoltaic (PV) irrigation system typically consist of a PV array, inverter (in the case of AC motor), controller, battery bank, a motor and other wiring accessory. With the use of DC pump, a DC-DC booster is utilized to step up and stabilize the voltage generated by PV cell. The general block diagram of DC and AC systems are shown in Fig (1 and Fig (2 respectively. The tilt angle of $\mathrm{PV}$ panel is an important parameter affecting the produced voltage, power and efficiency of solar cells, therefore it's an important factor to be kept in mind while designing the system.

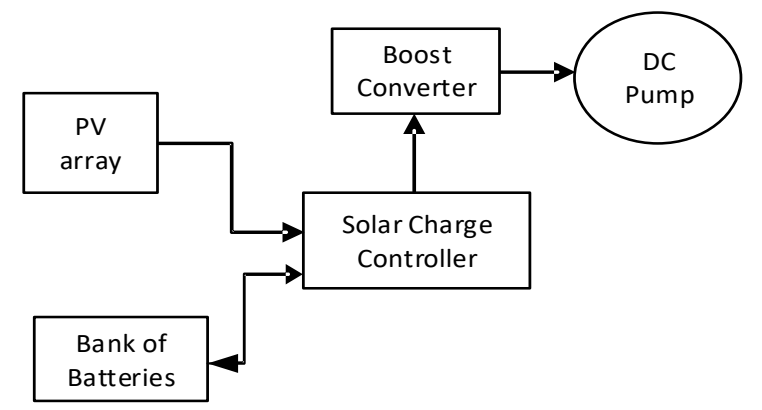

Fig (1) : Block Diagram of DC Motor Water Pumping Systems

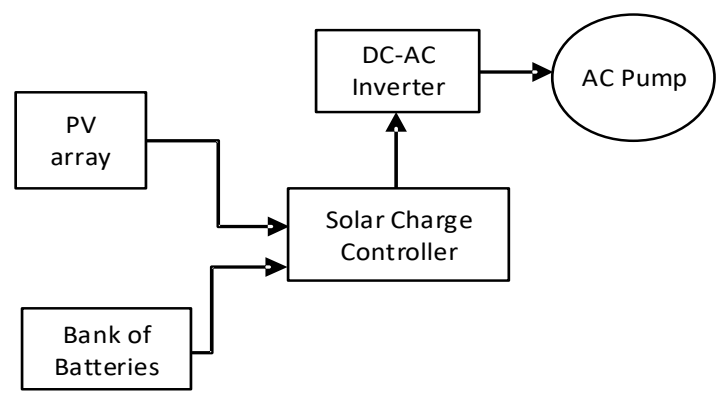

Fig (2) : Block Diagram of DC Motor Water Pumping Systems

\section{A. Solar PV Panels}

A photovoltaic array consists of one or more PV modules made of PV cells wired in series as well as in parallel to produce a specific voltage and current respectively under a given level of irradiance (Hamidat \& Benyoucef, 2009). Each cell of the module has at least two layers of semiconductor material which produce DC current upon exposure to sunlight. These layers are either made of the thin film or crystalline (Morales, 2010). Crystalline is mainly made of silicon while the thin film is made of metal and few metals are utilized for the purpose. The performance of a PV solar cell is generally evaluated by representing it as an electrical equivalent one diode model as shown in Fig (3.The diode current (Id) is the current produced by an inactive solar cell (at the absence of light), and series resistance (Rs) represents the internal resistance (Hansen, Sørensen, Hansen, \& Bindner, 2001). The voltage (V) and current (I) generated by PV cells depend upon the connection style of the cells and modules respectively. The product of current and voltage is the power produced by the PV cells array (Helikson, et al., 1990). 


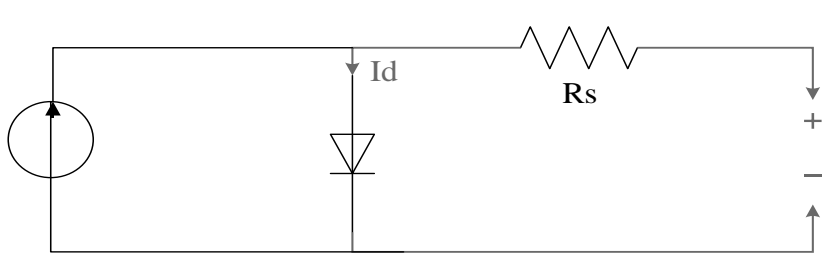

Fig (3) : Simplified Electrical diagram for

a PV module cell

Short circuit current is a linear function of ambient irradiation whereas the voltage changes slightly with it (Helikson, et al., 1990). Thus, solar PV panels with tracking systems may be adopted to improve the PV system performance. For improving the performance of PV cell panels, an alternative practical way can be used, by fixing the PV panel at some fixed tilt angles, which is plus or minus 15 degrees from the latitude of the location for winter and summer months respectively (Morales, 2010).

\section{B. Solar PV tilt angle}

Solar PV array performance is highly affected by its tilting angle with the horizontal. This is due to the fact that the value of solar radiation reaching the surface of PV panel changes with the change of tilt angle. The angle of PV arrays with respect to horizontal is defined as the tilt angle. The tilt angle is an important parameter affecting the collectible radiation of a fixed PV array. In general, the optimal tilt angle of a fixed PV array depends on the geographic latitude, climatic condition, and the period of its use. Therefore, different places will have different optimal tilt angles for a yearly used solar PV array. PV array adjustment of tilt angles in practical applications is direction should be toward the equator, in the northern hemisphere, the direction should face south. The optimum tilt angle depends on the latitude. (Imad Jawad Khadim, 2013) proved that changing collectors' azimuth and tilt angles daily to their optimum values in Egypt can achieve a total annual gain in solar radiation of $29.2 \%$ more than a fixed collector with a tilt angle equal to its geographic latitude. However, daily hard due to frequent changes of the angle and complex structure of frames which support solar panels. Monthly adjustment of tilt angle may be the simplest way and easier to be implemented in practice. In this mode of tilt-angle adjustment, the tilt angle of solar panels is only changed once per month with the tilt angle being site latitude $(\varnothing)$ around the equinoxes and $(\varnothing \pm \alpha)$ around the solstices, where $\alpha$ is the tilt-angle adjustment from the site latitude. The solar radiation amount incident on the surface is the component value of the incident radiation of received from the sun, which is perpendicular to the module surface. Fig (4 shows how to calculate the radiation incident on a tilted surface (Smodule) given either the solar radiation measured on the horizontal surface (Shoriz) or the solar radiation measured perpendicular to the sun (Sincident).

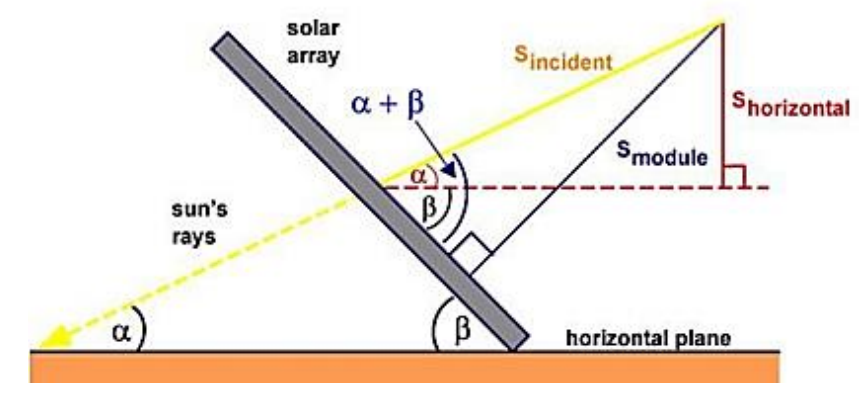

Fig (4) : Tilting the module to the incoming light reduces the module output

(Imad Jawad Khadim, 2013)

Equations (1) and (2) are relating Smodule, Shoriz, and Sincidentas (Gharakhani Siraki \& Pillay, 2012):

$\mathrm{S}_{\text {horizontal }}=\mathrm{S}_{\text {incident }} \sin \alpha$

$S_{\text {module }}=S_{\text {incident }} \sin (\alpha+\beta)$

where $\alpha$ is the elevation angle and $\beta$ is the tilt angle values of the module, which is measured from the horizontal.

The elevation angleis $\alpha$ is obtained as:

$\alpha=90-\emptyset+\delta$

where $\varnothing$ is the latitude angle and $\delta$ is the declination angle that given by:

$\delta=23.45^{\circ} \sin \left[\frac{360}{365}(284+d)\right]$

where $d$ is the day of the year.

The tilt angle is calculated as:

$\beta=90-\alpha$

\section{Batteries}

Mostly Solar PV powered irrigation system is designed for a complete off-grid application. Thus, it requires storing the power generated by the solar panels in batteries. The basic equivalent circuit of a lead acid battery is shown in Fig (5.

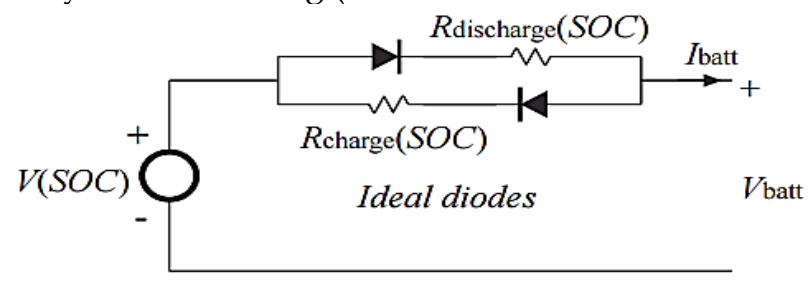

Fig (5) : Lead-acid battery equivalent circuit

They supply power to the solar charge controller, and water pump. The Nernst equation relates the chemical reaction energy to electrolyte energy is given by: 
$E=E^{\mathrm{o}}+(K T / q e)$

where $E$ is the energy at a given concentration, $E^{\mathrm{o}}$ is the energy at standard 1 molar concentration and $K T / q e=26 \mathrm{mV}$ at $298^{\circ} \mathrm{K}$.

\section{Solar Charge Controller}

The solar PV powered irrigation system uses a PWM charge controller; the controller is used to regulate the current and voltage coming from the PV array. The purpose of using this device is to protect the batteries from overcharging. The charge controller is a suitable choice based on the rated power of the panel.

\section{E. DC-DC boost converter}

Basic DC-DC booster can produce an output voltage greater than the source voltage. The basic electrical circuit DC-DC booster is shown in Fig (6. When the switching device is on, energy is stored in inductor $\mathrm{L}$, the energy stored in the inductor will discharge to capacitor $C$ and the load when the switch opens, by using Faraday`s law (Rashid, 2010):

$V_{s} D T=\left(V_{\mathrm{o}}+V_{s}\right)(1-D)$

Where $\mathrm{D}$ is the duty cycle.

From (7) the DC voltage transfer function is

$M_{V}=\frac{V_{\mathrm{o}}}{V_{S}}=\frac{1}{(1-D)}$

The booster circuit is used to step up the voltage produced by the PV cell before feeding to the pump system.

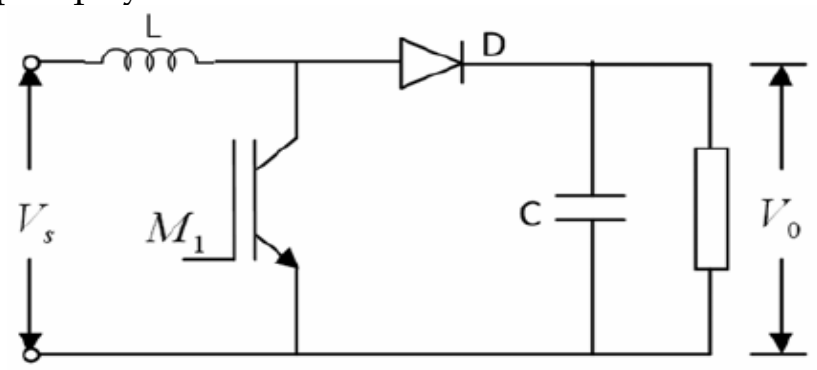

Fig (6) : DC-DC Boost Converter Circuit

(Sira-Ramirez, 2006)

\section{F. DC-AC Inverter}

Power inverters are used to convert electrical DC energy to electrical AC energy. They come in all sizes, from low to high power applications. The purpose of using a DC/AC power inverter is to transfer the DC power supplied by a battery, such as a 12 -volt battery, into a 120/220-volt AC power source operating at 50/60 $\mathrm{Hz}$. The equivalent circuit of single-phase full bridge inverter is shown in Fig (7.

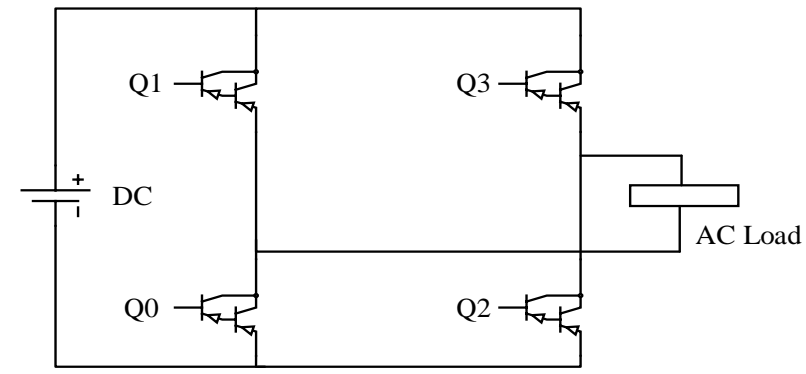

Fig (7) : Single Phase Full Bridge Inverter

In Fig (7, Q0, Q1, Q2, and Q3 are power transistors. G. Water Pump Model

DC Pump

The criterion for the pump's selection of the system is low cost to assure affordability on the part of small farms. In developed countries, diaphragm pumps are used for water supply to communities. The diaphragm pump is used in this prototype because these pumps are the cheapest in the market and are already known in the project's area.

The motor of the pump is a DC Permanent Magnet. The circuit diagram of the permanent magnet motor is shown in Fig (8 (Chandrasekaran \& Thyagarajah, 2014). The voltage of the motor is given by:

$V=E+I R+V_{b}$

where $V$ is the applied voltage, $E$ is the motor back e.m.f, $I$ is the current of the armature, $R$ is the armature resistance and $V_{b}$ is the brushes voltage drop.

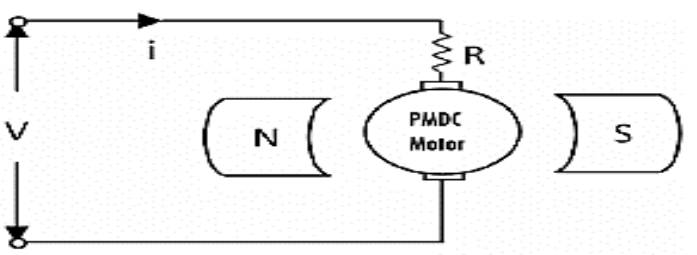

Fig (8) : Permanent Magnet DC Motor

(Chandrasekaran \& Thyagarajah, 2014)

\section{AC Pump}

AC induction motors are known as the most common motors that are used in industrial motion control systems, as well as in main powered home appliances.

The main advantages of $\mathrm{AC}$ induction motors are their simple and rugged design; their direct connection to an AC power source, and their low initial cost and maintenance. The equivalent circuit of the induction $\mathrm{AC}$ motor is shown in Fig ( 9. 


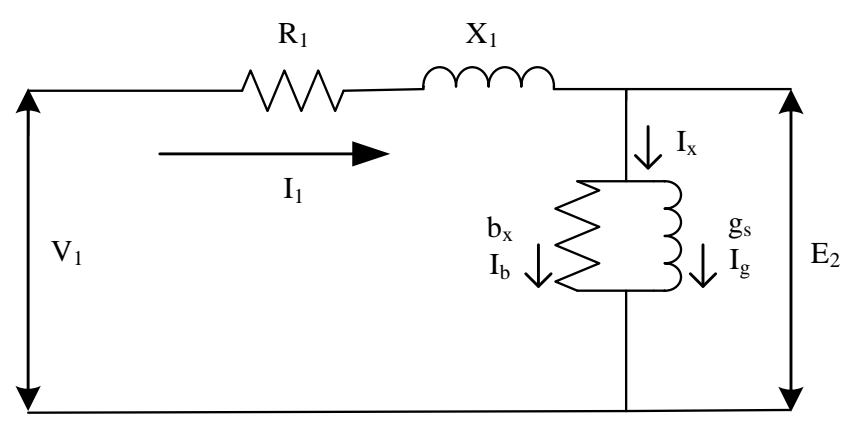

Fig ( 9) : AC Induction Motor

In Fig. 9, $V_{1}$ is the terminal voltage of the stator, $I_{1}$ is the stator current, $X_{1}$ is the stator leakage reactance, $R_{1}$ is the stator effective resistance, $E_{2}$ is the counter ElectroMotive Force (EMF) generated by the air gap flux, $I_{X}$ is the excitation current and $Z_{1}$ is the impedance of the stator.

\section{DESIGN OF THE PROPOSED PV-powered MOTOR SYSTEM FOR IRRIGATION}

In this section, the design of the proposed PV system is presented. Also, the main components of the system are modeled in Matlab Simulink for performance verifications.

\subsection{Design of the Prototype}

The prototype consists of a PV array, controller, a motor, battery bank, DC-DC converter in case of DC pump, and DC-AC inverter in case of AC pump and other mounting and wiring accessories. In this study, only one PV-panel is used. The panel consists of four NR50G PV modules manufactured by the Naps Systems Oy Finland. Each module consists of 36 polycrystalline silicon cells connected in series that can produce maximum power (Pmax) of 50 watts at standard conditions. Specifications of the panel at STC (i.e. $25^{\circ} \mathrm{C}$ and $1.000 \mathrm{~W} / \mathrm{m}^{2}$ ) are given in Table 1 .

TABLE (1) : Specifications of PV cell panel

\begin{tabular}{|c|c|}
\hline Component & Value \\
\hline Nominal power & $50.0 \mathrm{~W}$ \\
\hline Open circuit Voltage & $21.1 \mathrm{~V}$ \\
\hline MPP voltage & $16.7 \mathrm{~V}$ \\
\hline Short circuit current & $3.20 \mathrm{~A}$ \\
\hline MPP current & $3.00 \mathrm{~A}$ \\
\hline
\end{tabular}

One important condition to be noticed; is that operating temperatures of these PV modules in Iraq are usually higher than $25^{\circ} \mathrm{C}$. However, PV panels operating at higher temperatures than $25^{\circ} \mathrm{C}$ produces less than their rated output power (Masters, 2004). Thus due to temperature affect, their efficiency drops below the rated values. The efficiency of these modules is $13.5 \%$ at standard test conditions. The modules are connected in parallel via multiple contact connectors to maintain approximately 18 volts. To measure the performance of the panel, the positive side wires of the panel is connected to current sensors before it is connected to the charge controller. Also, positive and negative wires from the panel are connected to relevant charge controller terminals. In this study, one 12 volts' leadacid battery is used. The battery can deliver up to 105 amp-hours of energy at 12 volts. Continues power is provided by the battery for the duration of 50 hours of pumping operation.

Backup power is provided for the system to run continuously in case of overcast weather. The charge controller used can supply a maximum of 45 amps current from the PV array to the batteries. Since the proposed PV array consists of only one PV panel, the charge controller can deliver a maximum current of 17.32 amps. The controller has four terminal connectors; two terminals are connected to positive and negative terminals of the batteries, the other two terminals feed the positive and negative leads from the PV array. Boost converter is used to step up the panel voltage of $16-17 \mathrm{~V}$ (depending on the sunshine) to $24 \mathrm{~V}$. A Daygreen brand boost converter is used, the values of the components of the booster are, $\mathrm{V}_{\text {in }}=17 \mathrm{~V}, \mathrm{~V}_{\text {out }}=24 \mathrm{~V}$, Duty Cycle, $\mathrm{D}=0.5$, $\mathrm{I}_{\text {ripple }}=0.117 \mathrm{~A}, \mathrm{~L} 1=1.004 \mathrm{mH}$, Cout $=211 \mu \mathrm{F}, \mathrm{I}_{\text {diode }}=15.1689$ A. A DC permanent magnet motor $(16 \mathrm{~W}), 24 \mathrm{~V}$, Shurflo ProBaitmaster pump model $4901-6212$ is selected to perform this study. The DC motor is directly connected to solar PV panel to see the motor performance. Motor performance without using any converter was not satisfactory as it could not supply the required initial torque of the motor. Since the motor used is $24 \mathrm{~V}$, a boost converter is used to provide initial high voltage to the motor for starting purpose and smooth running of the motor. The performance improved after the integration of boost converter.

In Case of AC pump, a submersible AC pump is used. Rated voltage, rated current and rated power of motor are $240 \mathrm{~V}, 0.1 \mathrm{~A}$, and $16 \mathrm{~W}$ respectively. This motor is chosen due to its low economic cost.

\subsection{System Simulation}

To be sure that the system performance and components are accurate, specifications are tested in Matlab Simulink.

PV array is modeled in Matlab Simulink for performance verifications. The model is implemented as shown in Fig (10. 


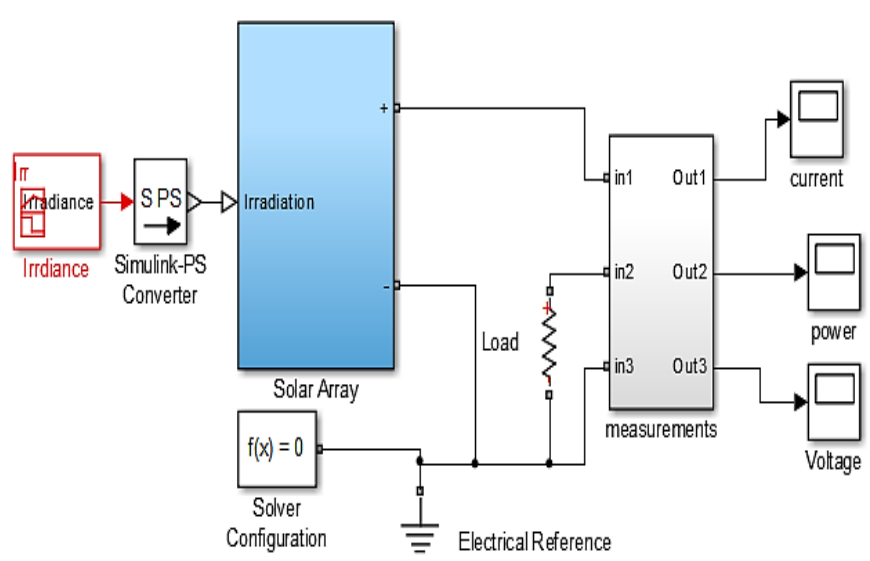

Fig (10) : Simulink diagram of PV cell panel

DC motor is also modeled in Matlab Simulink to verify its performance. DC motor Simulink model is shown in Fig (11.

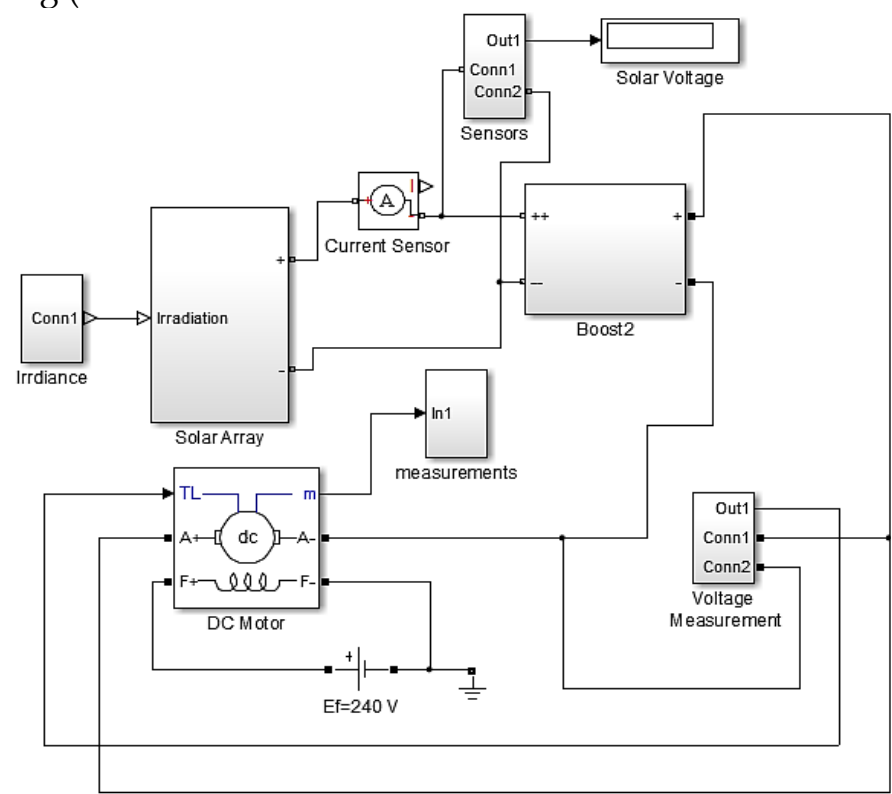

Fig (11) : Simulink diagram of PV based DC motor

AC Motor system is designed in Matlab Simulink to analyze the specifications and accuracy of the motor; Simulink design is shown in Fig (12.

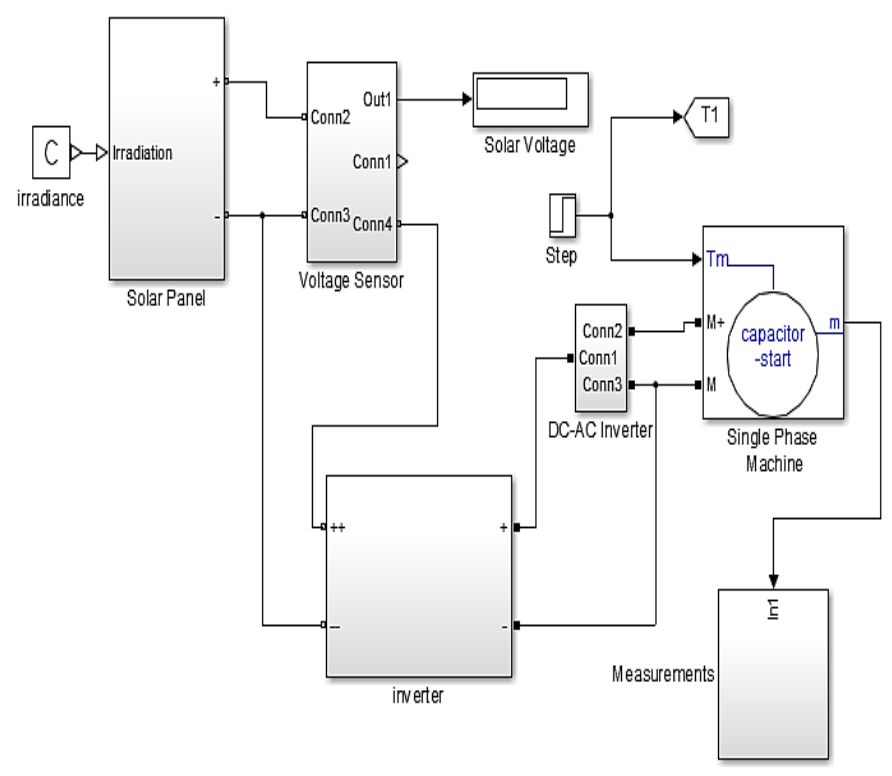

Fig (12) : Simulink diagram of PV based AC motor

\section{Results And Discussion}

In this section, experimental results are obtained practically. A comparison between DC and AC motor pumps is carried out. Selecting optimum tilt angle for Duhok is calculated and performed practically.

\subsection{Selecting Optimum Tilt Angle}

The system designed in section three is tested experimentally. The results are obtained and analyzed. Three different tilt angles are calculated using (5): $1.39 .4^{\circ}$ : the optimum tilt angle of 26 th of September.

2.34.8 ${ }^{\circ}$ : the average angle for the month of September.

$3.22^{\circ}$ : the average angle for 4 months (June, July, August, and September).

Fig (13 and Fig (14 show different values of solar Irradiation and PV panel output voltage respectively for different angles and hours of the day.

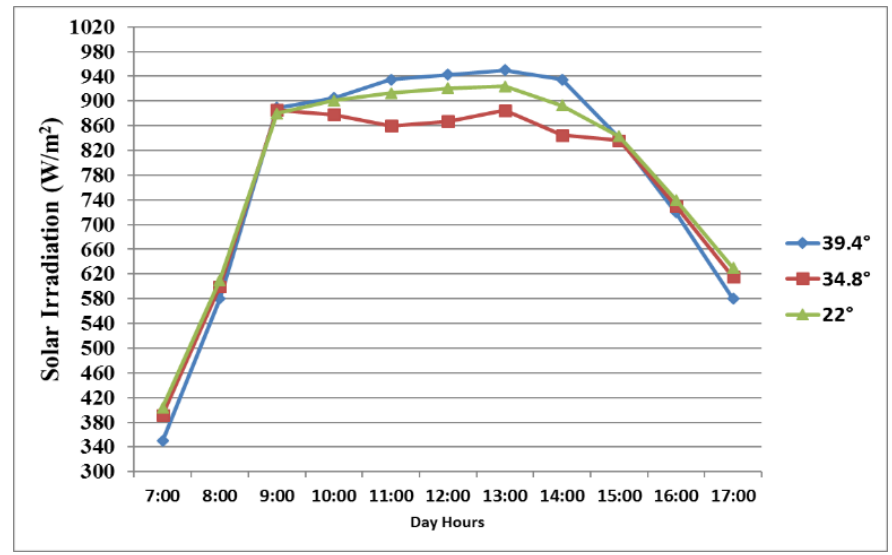

Fig (13) : Solar Irradiance for different tilt angles 


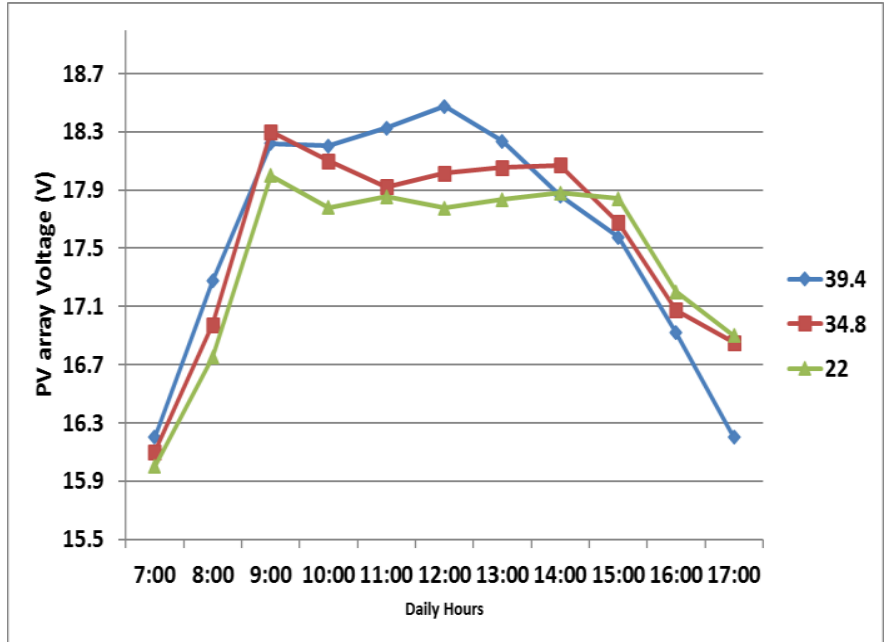

Fig (14) : PV produced voltage for different tilt angles

Fig (13 and Fig (14 shows that the best tilt angle to get maximum output voltage is $39.4^{\circ}$. However, changing the angle daily is impractical. Therefore, the month average angle $34.8^{\circ}$ is selected to be the optimum tilt angle of month September.

\subsection{Performance of the Proposed System in Case of DC Pump}

The tilt angle for solar panels is set-up to $34.8^{\circ}$ (optimized chosen angle) south facing in the garden of the college of engineering in Duhok city. The DC motor is connected to PV cells. The boost converter is connected between motor-pump and solar PV panel to improve the performance of the system. Data are collected over a period of few hours on a summer day and listed in Table 2.

TABLE (2) : Characteristics data of the solar pump connected with boost converter

\begin{tabular}{|c|c|c|c|c|c|c|c|}
\hline 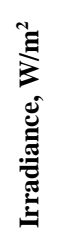 & 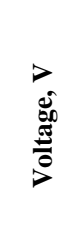 & 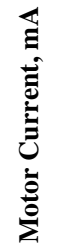 & 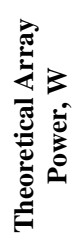 & 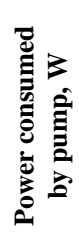 & 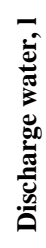 & 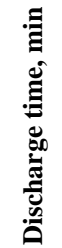 & 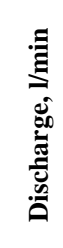 \\
\hline 905 & 18.2 & 210 & 166 & 3.612 & 0.5 & 0.45 & 0.7 \\
\hline 935 & 18.33 & 220 & 168 & 3.872 & 0.5 & 0.4 & 0.75 \\
\hline 943 & 18.5 & 230 & 176 & 4.14 & 0.5 & 0.38 & 0.78 \\
\hline 950 & 18.65 & 240 & 179 & 4.392 & 0.5 & 0.36 & 0.83 \\
\hline 845 & 17.9 & 270 & 180 & 5.022 & 0.5 & 0.34 & 0.69 \\
\hline 835 & 17.6 & 290 & 182 & 5.481 & 0.5 & 0.31 & 0.66 \\
\hline
\end{tabular}

From Table 2, it is clear that the characteristic of the solar powered pump is similar to the theoretical characteristics. However, the power consumed by the water pump is less than the theoretical power of the array. It is found that the water discharge capacity is in the range of $0.91 / \mathrm{min}$.

\subsection{Performance of the Proposed System in Case of AC Pump}

To see the performance of the system with solar PV cells, a load test is performed with the motor pump set is directly connected to the solar panels through an inverter. Detailed performance of the system is recorded in Table 3. Data are collected over a period of few hours of a summer day.

TABLE (3) : Characteristics data of the solar powered AC pump

\begin{tabular}{|c|c|c|c|c|c|c|}
\hline 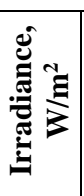 & 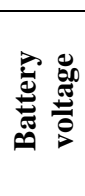 & 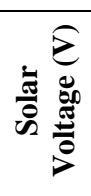 & 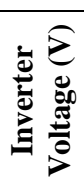 & 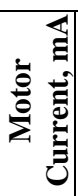 & 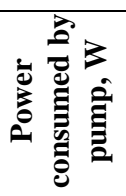 & 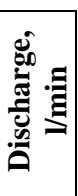 \\
\hline 905 & 10.2 & 18.2 & 229 & 80 & 18.32 & 1.2 \\
\hline 935 & 10.8 & 18.33 & 230.3 & 79 & 18.1937 & 1.4 \\
\hline 943 & 11.25 & 18.5 & 231 & 78 & 18.018 & 2 \\
\hline 950 & 11.5 & 18.2 & 232 & 77 & 17.864 & 2.1 \\
\hline
\end{tabular}

\subsection{Cost of the Proposed System}

Using locally available technologies, DC and AC water pump powered by solar PV is designed and implemented to study the way to reduce dependency on conventional electricity and diesel water pumps that used in irrigation. Moreover, since these dc pumps will run without an inverter, maintenance will also be less and easy. Total costs of the proposed systems are shown in Table 4 and Table 5.

TABLE (4) : Total cost of the DC system

\begin{tabular}{|c|c|}
\hline Component & Price \\
\hline PV panel & $300 \$$ \\
\hline DC-DC converter & $8 \$$ \\
\hline DC pump & $15 \$$ \\
\hline Total & $323 \$$ \\
\hline
\end{tabular}

TABLE (5) : Total cost of AC system

\begin{tabular}{|c|c|}
\hline Component & Price \\
\hline PV panel & $300 \$$ \\
\hline DC-AC inverter & $215 \$$ \\
\hline AC pump & $12 \$$ \\
\hline Total & $527 \$$ \\
\hline
\end{tabular}

\subsection{Discussion of Results}

AC and DC systems are compared in terms of system complexity, cost as shown in Tables 4 and 5, and power consumption. From Table 3 and table 4, the DC motor consumes less power than the AC and the system uses fewer components i.e. the system is simpler, also the DC system is more cost effective than the AC. On the other hand, the water discharge of the AC pump is higher 
than the DC pump for the same time (see Table 2 and Table 3). However, the overall results showed the superiority of the DC motor over the AC motor.

\section{Conclusion}

This study presented a design of a standalone PVpowered irrigation system. A comparison was carried out between AC and DC motor pumps. The results demonstrated the advantage of DC motor over AC in terms of system simplicity, cost, and power consumption. On the other hand, water discharge of AC pump was higher than the DC pump for the same time, the average water discharge of $\mathrm{AC}$ motor was around $1.3 \mathrm{l} / \mathrm{m}$ while $0.83 \mathrm{l} / \mathrm{m}$ for DC motor. However, overall results showed the superiority of DC motor over AC motor. Therefore, DC motor was selected to be used in the proposed system. The system was designed and implemented considering the effect of solar radiation on motor power, current, and water discharge. The system was also modeled and simulated in Matlab Simulink. The system was tested with an optimum tilt angle for Duhok city. The results showed that choosing the optimum tilt angle affects directly the amount of incident irradiation, which affects proportionally the water discharge of the pump. It is concluded that the tilt angle of the panel can be changed manually once a month to avoid the using of the solar tracking system. Finally, the results demonstrated that the prototype is effective in irrigation systems in terms of water discharge value, accuracy and cost.

\section{REFERENCES}

1.(FAO)., F. a. A. O. o. t. U. N. (2016). solar-waterpumps. Retrieved 08.07.2016, from Food and Agriculture Organization of the United Nations (FAO). 2. Al-Ali, A., Rehman, S., Al-Agili, S., Al-Omari, M., \& Al-Fayezi, M. (2001). Usage of photovoltaics in an automated irrigation system. Renewable energy, 23(1), 17-26.

3.Chandrasekaran, N., \& Thyagarajah, K. (2014). Simulation and experimental validation of AC motor and PMDC motor pumping system fed by photovoltaic cell.

4.Cuadros, F., López-Rodriguez, F., Marcos, A., \& Coello, J. (2004). A procedure to size solar-powered irrigation (photoirrigation) schemes. Solar energy, 76(4), 465-473.

5. Gharakhani Siraki, A., \& Pillay, P. (2012). Study of optimum tilt angles for solar panels in different latitudes for urban applications. Solar Energy, 86(6), 1920-1928.

6. Hamidat, A., \& Benyoucef, B. (2009). Systematic procedures for sizing photovoltaic pumping system, using water tank storage. Energy Policy, 37(4), 14891501.

7.Hansen, A. D., Sørensen, P. E., Hansen, L. H., \& Bindner, H. W. (2001). Models for a stand-alone PV system (Report No. 87-550-2774-1). Denmark: Technical University of Denmark, Frederiksborgvej

8. Helikson, H. J., Haman, D. Z., \& Baird, C. D. (1990). Pumping water for irrigation using solar energy. EESFlorida Cooperative Extension Service.

9. Imad Jawad Khadim, E. J. M., Ali Hussian Ubaid (2013). Determining Tilt Angle for Fixed Solar Panel Tosites of Iraq's Provinces by Using the Programs on NASA and Google Earth Websites. Eng. \&Tech, 32, 2-5.

10. Masters, G. M. (2004). Renewable and efficient electric power systems (Second edition. ed.). Hoboken, New Jersey.: John Wiley \& Sons, Inc., .

11. Morales, T. D. (2010). Design of Small Photovoltaic (PV) Solar-Powered Water Pump Systems (No. 28). PORTLAND, OREGON

12. Rashid, M. H. (2010). Power electronics handbook: devices, circuits and applications: Academic press.

13. Sira-Ramirez, H., Silva-Ortigoza, Ramón. (2006). Control Design Techniques in Power Electronics Devices. http://www.springer.com/978-1-84628-458-8: Springer. 